\title{
FAKTOR YANG MEMPENGARUHI ETNIS DAYAK DENGAN ETNIS JAWA UNTUK MELAKUKAN PERKAWINAN CAMPURAN
}

\author{
Mardiana \\ Sekolah Tinggi Keguruan Dan Ilmu Pendidikan Melawi \\ Email: mardianaleona@gmail.com
}

\begin{abstract}
Abstrak
Latar belakang masalah penelitian ini adalah masuknya etnis Jawa melaui program transmigrasi. Hal ini, mengakibatkan terjadinya perkawinan campuran antar etnis Dayak dengan etnis Jawa dengan perbedaan latar belakang etnis, agama, bahasa, dan budaya Penelitian ini bertujuan untuk menganalisis faktor-faktor yang mempengaruhi etnis Dayak dengan etnis Jawa untuk melakukan perkawinan campuran di Desa Tanjung Sari Kecamatan Nanga Pinoh Kabupaten Melawi. Metode penelitian ini menggunakan metode case study dengan teknik purposive sampling. Hasil penelitian menunjukkan bahwa faktor-faktor yang mempengaruhi etnis Dayak dengan etnis Jawa untuk melakukan perkawinan campuran di Desa Tanjung Sari, yaitu faktor ketertarikan fisik dan inklusifitas ( keterbukaan, fleksibilitas, toleransi, dan kepekaan terhadap pasangan).
\end{abstract}

Kata Kunci: Etnis Dayak; Etnis Jawa; perkawinan campuran;

\begin{abstract}
The background to this research problem is the inclusion of Javanese through the transmigration program. This resulted in a problem that caused mixed marriages between ethnic Dayak and Javanese with different ethnic, religious, linguistic and cultural backgrounds. This study aims to analyze the factors that influence Dayak ethnicity with Javanese ethnicity to conduct mixed marriages in Tanjung Village Sari, This research method uses the case study method. Data collection techniques through interview, observation, and documentation. The subject of this research were intermarried couples of mixed marriage couples, parent of mixed marriages, community leader, and traditional leaders with purposive sampling technique. The results showed that the factors that influenced Dayak ethnicity with Javanese ethnicity to conduct mixed marriages in Tanjung Sari Village were factors of physical attraction and flexibility (openness, flexibility, tolerance, and sensitivity to partners).
\end{abstract}

Keywords: Dayak Ethnic; Javanese Ethnic; intermarriage;

\section{PENDAHULUAN}

Salah satu provinsi di Indonesia yang memiliki etnis yang beragam adalah di Desa Tanjunga Sari Kecamatan Nanga Pinoh Kabupaten Melawi. Penduduk di Kecamatan Nanga Pinoh terdiri dari etnis Dayak, Melayu, Jawa, Tionghoa, Madura, Bugis, Padang, Sunda dan lain sebagainya yang berbeda dalam bahasa, tradisi, norma dan adat istiadatnya. 
Etnis Dayak, sebagaimana etnis bangsa lainnya memiliki kebudayaan atau adat istiadat tersendiri yang tidak sama dengan etnis bangsa lainnya di Indonesia. Adat istiadat yang hidup di dalam masyarakat etnis Dayak merupakan unsur terpenting, akar identitas bagi masyarakat Dayak. Dayak merupakan istilah yang menunjuk kepada orang-orang non muslim atau non-melayu yang merupakan penduduk asli Kalimantan.

Etnis Dayak memiliki adat istiadat yang mudah dikenal, yaitu terlihat dengan bahasa khas, tariannya, cara berpakaian, cara menjalani kehudupannya, serta upacara atau ritual yang dilakukan. Adat istiadat yang beragam inilah yang menjadi corak kebudayaannya.

Melihat dari latar belakang budayannya Dayak dan Jawa merupakan dua budaya yang berbeda. Bagi individu dari etnis Jawa identik dengan sikap sopan, segan, cenderung tunduk, lemah lembut dan tidak pernah bertindak kata-kata kasar. Budaya Jawa juga dikenal dengan seseorang yang sangat menjunjung etika, baik secara sikap maupun berbicara. (Endraswara, 2015).

Sejarah awal kedatangan orang Jawa yang datang ke Kalimantan terjadi sekitar tahun 1880 sampai 1940 Masehi baik sebagai buruh yang dikirim oleh Pemerintah Hindia Belanda maupun atas dasar keinginan sendiri untuk mengadu nasib yang lebih baik (Thamrin, 1988 : ).Etnis Jawa yang datang ke Kalimantan Barat dan derah-daerah lainnya, diantaranya yang terdapat di Desa Tanjung Sari kecamatan Nanga Pinoh Kabupaten Melawi merupakan etnis pendatang yang yang berasal dari Pulau Jawa yang terdiri dari Jawa Tengah, Jawa Barat, dan Jawa Timur.

Masyarakat etnis Jawa hidup berbaur dengan masyarakat lokal yaitu beretnis Dayak dan mengadakan suatu hubungan satu sama lain serta dapat hidup bersama-sama dengan damai, saling menyesuikan diri baik melalui hubungan perkawinan maupun melalui kerjasama dalam lapangan ekonomi. Salah satu penyebab terjadinya perkawinan campuran yang ada di Desa Tanjung Sari Kecamatan Nanga Pinoh dikarenakan adanya program transmigrasi, sehingga terjadinya interaksi yang berlangsung secara intensif. Latar belakang etnis Dayak dengan etnis Jawa berbeda, akan tetapi dapat hidup berdampingan di masyarakat, 
etnis Dayak dan etnis Jawa juga hidup berkelompok dan membaur dengan etnis lain sehingga menyebabkan terjadinya perkawinan campuran antar etnis Dayak dengan etnis Jawa di Desa Tanjung Sari Kecamatan Nanga Pinoh.

Pengertian perkawinan campuran ialah perkawinan antara dua orang yang di Indonesia tunduk pada hukum yang berlainan karena perbedaan kewarganegaraan dan salah satu pihak berkewarganegaraan Indonesia (pasal 57 Undang-Undang No.1 Tahun1974). Maksud pengertian perkawinan campuran di atas yaitu perkawinan yang dilakukan antara warga negara Indonesia dengan warga negara asing, sedangkan pengertian perkawinan campuran yang ada di Indonesia dalam hal ini yaitu bertemunya pasangan antar etnis yang berlawanan jenis yang mengikat janji untuk hidup bersama, memiliki latar belakang budaya yang berbeda sehingga dapat diterima untuk menjadi teman hidup selamanya dalam menjalankan rumah tangga bersama.

Dodd (1998: 70-71) menggolongkan delapan kategori yang dapat mempengaruhi perkawinan campuran sebagai berikut: (1) efek Romeo dan Juliet: Konsep ini merujuk pada pasangan kawin campur yang saling tertarik, meskipun keluarga masing-masing tidak memberikan restu. (2) peran yang diharapkan: Beberapa studi memperlihatkan, bahwa para isteri merasa dipaksa untuk menerima budaya suaminya., (3) gangguan dari keluarga besar: Bagi keluarga kawin campur, persoalan seputar ikut campurnya atau evaluasi oleh keluarga besar lebih sering dijumpai dibandingkan dengan keluarga yang menikah dalam satu budaya, (4) budaya kolektif-individualistik: beberapa budaya menganut pendekatan saling berbagi sesuai dengan komitmen dan tanggung jawab dalam kelompok (keluarga besar), (5) bahasa dan kesalahpahaman: ketika dua bahasa yang berbeda dipakai dalam kehidupan sehari-hari keluarga kawin campur, seringkali menghasilkan konflik, paling tidak persoalan kesalahpahaman terhadap kata-kata, bahasa yang dipilih untuk dipakai seharihari, (6) model konflik: Perbedaan dalam cara memecahkan konflik juga merupakan poin penting kehidupan pasangan kawin campur. Directnessindirectness, budaya konteks tinggi konteks rendah, dan jarak kekuasaan merupakan faktor-faktor yang berhubungan dengan konflik dalam keluarga 
kawin campur, (7) cara membesarkan anak: perilaku terhadap anak dan cara mendidik anak merepresentasikan perbedaan budaya yang lain dalam keluarga kawin campur. Beberapa budaya menganut pemberlakuan aturan yang ketat dibandingkan budaya lain, yang akan menghasilkan nilai budaya yang berbeda, sekaligus perbedaan cara nilai-nilai tersebut dikomunikasikan dan diberlakukan kepada anak-anak, (8) pandangan negatif dari komunitas : Dodd (1998: 71) mengajukan pertanyaan kepada 549 orang tentang perkawinan orang Yahudi. Hasilnya, 25 persen beranggapan, bahwa perkawinan antara orang Yahudi Barat dengan Yahudi Timur tidak akan berhasil dalam perkawinannya.

Perkawinan dengan etnis yang sama merupakan suatu kebiasaan yang sering kita jumpai bahkan sampai dengan perkawinan antar etnis, yang memiliki berbagai macam permasalahan. Tidak semua pernikahan beda etnis dapat berjalan dengan baik, dengan perbedaan tersebut dapat menimbulkan hambatan dalam proses pelaksanaan perkawinan karena adanya latar belakang kebudayaan, tradisi, agama, dan bahasa yang berbeda serta kerangka pola berfikir setiap individu yang berbeda. Secara sosial mereka akan mengalami persepsi negatif dari masyarakat dan berkembang stereotip pada masyarakat umum yang memiliki persepsi negatif terhadap pasangan yang melakukan perkawinan campuran antar etnis.

Berdasarkan pada permasalahan tersebut, maka dalam penelitian ini dipilih judul "Faktor-faktor yang mempengaruhi etnis Dayak dengan etnis Jawa untuk melakukan perkawinan campuran (studi kasus di Desa Tanjung Sari Kecamatan Nanga Pinoh Kabupaten Melawi)". Tujuan penelitian ini dimaksudkan untuk menganalisis faktor-faktor yang mempengaruhi etnis Dayak dengan etnis Jawa untuk melakukan perkawinan campuran. Penelitian ini diharapkan dapat bermanfaat bagi: Pasangan perkawinan campuran antar etnis untuk saling memahami perbedaan dalam menjalani kehidupan rumah tangga yang harmonis.

\section{METODE}


Penelitian ini dilaksanakan di Desa Tanjung Sari, salah satu Desa di Kecamatan Nanga Pinoh Kabupaten Melawi. Desa Tanjung Sari dikenal sebagai desa transmigrasi yang penduduknya mayoritas beretnis Jawa dan ditambah dengan penduduk asli setempat yang ikut program transmigrasi sisipan. Informan dalam penelitian ini adalah empat pasangan kawin campur antar etnis Dayak dengan etnis Jawa, tokoh masyarakat, tokoh adat, dan keluarga pasangan kawin campur antar etnis Dayak dengan etnis Jawa. Informan penelitian dipilih dengan teknik purposive sampling.

Berdasarkan karakteristik tersebut, peneliti dapat memperoleh sampel sebanyak tujuh orang, terdiri empat orang informan utama dan dua orang informan pendukung. Berikut data sampel penelitian ini disajikan pada tabel berikut:

Tabel 1. Identitas Informan Utama Penelitian

\begin{tabular}{llllll}
\hline No & $\begin{array}{l}\text { Nama } \\
\text { Pasangan }\end{array}$ & Umur & Etnis & Pekerjaan & $\begin{array}{l}\text { Usia } \\
\text { Perkawinan }\end{array}$ \\
\hline 1 & Wn & 39 & Jawa & Petani & 7 tahun \\
& Lt & 35 & Dayak & RT & \\
2 & Al & 45 & Dayak & Swasta & 16 tahun \\
& Jm & 38 & Jawa & RT & \\
3 & Ys & 45 & Jawa & Swasta & 18 tahun \\
& Rn & 39 & Dayak & RT & \\
4 & $\mathrm{Ag}$ & 47 & Dayak & Swasta & 33 tahun \\
& Ni & 39 & Jawa & Rt & \\
\hline
\end{tabular}

Sumber : hasil wawancara di Desa Tanjung Sari

Tabel 2. Identitas Informan Pendukung Penelitian

\begin{tabular}{|c|c|c|c|c|c|}
\hline No & Nama & Umur & Etnis & Pekerjaan & Keterangan \\
\hline 1 & $\mathrm{Tf}$ & 55 & Jawa & Petani & $\begin{array}{l}\text { Tokoh } \\
\text { Masyarakat }\end{array}$ \\
\hline 2 & At & 75 & Dayak & Petani & $\begin{array}{l}\text { Temenggung } \\
\text { Adat Dayak }\end{array}$ \\
\hline 3 & Sm & 70 & Jawa & Petani & Orang Tua Lt \\
\hline
\end{tabular}

Sumber: hasil wawancara di Desa Tanjung Sari

Penelitian ini menggunakan teknik purposive sampling yaitu subyek dipilih dengan pertimbangan dan tujuan tertentu. Data dalam penelitian ini 
diperoleh melalui wawancara, observasi, dan dokumentasi. Teknik umum yang digunakan selama penelitian adalah wawancara langsung, yaitu berhadapan langsung dengan subyek penelitian. Tujuan data diperoleh sesuai dengan apa yang disampaikan oleh informan, hasil wawancara direkam menggunakan handphone. Observasi dilakukan untuk melengkapi data-data yang diperoleh melalui wawancara dan mengamati peristiwa yang terjadi di lingkungan subyek penelitian. Dokumentasi berupa dokumen yang terkait dengan tema penelitian Metode analisis data yang digunakan dalam penelitian yaitu metode analisis kualitatif. Data dianalisis dengan menggunakan metode induktif, yaitu suatu analisis dan penarikan kesimpulan dari yang khusus ke umum. Adapun tahapan analisis data kualitatif dalam penelitian ini dengan teknik analisis interaktif menggunakan model Miles dan Huberman (Creswell, 2014: 274-284; Sugiyono, 2014: 91-99), terdiri dari empat tahapan, yaitu : (1) pengumpulan data, (2) reduksi data (data reduction), (3) penyajian data (data display), (4) penarikan kesimpulan atau verifikasi (consclusion drawing).

\section{HASIL DAN PEMBAHASAN}

Menurut Lewis (1997:68) yang menyebabkan terjadinya perkawinan campuran, antara lain: (1) ketertarikan fisik, (2) kesamaan sosial dan ekonomi, (3) perbaikan keturunan. Ada empat indikator dalam faktor-faktor yang mempengaruhi terjadinya perkawinan campuran antar etnis Dayak dengan etnis Jawa, yaitu ketertarikan fisik, kesamaan sosial dan ekonomi, perbaikan keturunan dan inklusifitas (keterbukaan, fleksibilitas, toleransi, dan kepekaan terhadap pasangan).

\section{Ketertarikan Fisik}

Latar belakang fisik memang faktor utama penentu terjadinya pernikahan, melalui fisik seseorang dapat melihat penampilan pasangannya yang tampak oleh mata. Untuk menghasilkan keturunan yang baik maka diperlukan calon pasangan yang lebih baik. Hal semacam ini tidak selalu 
didapatkan dari pasangan dengan suku yang sama, melainkan juga bisa didapatkan dari seseorang dengan suku berbeda. Hasil penelitian yang dinyatakan oleh subyek penelitian menunjukkan bahwa selain karena cinta faktor fisik juga merupakan salah faktor yang mempengaruhi terjadinya perkawinan campuran, karena antara fisik dan cinta saling terkait. Apabila seseorang tertarik karena fisik seperti ketampan, kecantikan maka akan tumbuh rasa cinta dan menjadi suatu kebanggan bagi pasangan apabila memiliki pasangan hidup sesuai dengan kriteria yang diinginkan.

Faktor ketertarikan fisik merupakan salah satu faktor yang mempengaruhi terjadinya perkawinan campuran antar etnis Dayak dengan etnis Jawa di Desa Tanjung Sari, bermula dari fisik sehingga tumbuhnya rasa cinta, dengan di dukung perilaku dan sikap dari pasangan tersebut yang berakhir dijenjang perkawinan, selain faktor ketertarikan fisik terdapat faktor-faktor lainnya yang mempengaruhi perkawinan campuran antar etnis yaitu kesamaan sosial dan ekonomi.

\section{Kesamaan Sosial dan Ekonomi}

Latar belakang status sosial dan ekonomi tidak jarang menjadi pertimbangan seseorang dalam memilih pasangan hidupnya. Orang hanya akan menikah dengan seseorang yang latar belakang status ekonominya sudah mapan. Bukan hanya yang bersangkutan yang bersifat demikian, tetapi juga pihak orang tua dan kerabat lainnya. Sebaliknya, ada pihak yang tidak bersedia menikah dengan pasangan yang tingkat status ekonominya lebih tinggi karena khawatir dia akan dijajah nanti oleh pasangannya dalam rumah tangga.

Faktor kedua yang menyebabkan terjadinya perkawinan campuran yaitu karena kesamaan sosial dan ekonomi, faktor ini tidak mempengaruhi pasangan yang akan melangsungkan perkawinan antar etnis di Desa Tanjung Sari, Kecamatan Nanga Pinoh.

Faktor kesamaan sosial dan ekonomi tidak menjadi faktor utama yang mempengaruhi terjadinya perkawinan campuran antar etnis Dayak dengan etnis Jawa di Desa Tanjung Sari. Latar belakang pendidikan yang masih tergolong 
rendah setiap pasangan suami istri kawin campur tidak menuntut dan melihat pendidikan pasangannya ketika akan memutuskan ke jenjang perkawinan.

Latar belakang pendidikan pasangan kawin campur antar etnis Dayak dengan etnis Jawa di Desa Tanjung Sari, berikut data pendidikan yang ditempuh oleh pasangan kawin campur antar etnis Dayak dengan etnis Jawa:

Tabel 3. Data Pendidikan Terakhir Pasangan Kawin Campur Antar Etnis Dayak dengan Etnis Jawa di Desa Tanjung Sari

\begin{tabular}{llllll}
\hline No & \multicolumn{2}{c}{ Nama } & \multicolumn{2}{c}{$\begin{array}{c}\text { Pendidikan } \\
\text { Terakhir }\end{array}$} & \multicolumn{1}{c}{ Keterangan } \\
& & Suami & \multicolumn{1}{c}{ Istri } \\
\hline 1 & Wn & It & SD & SD & STM tidak lanjut \\
2 & $\mathrm{Al}$ & $\mathrm{Jm}$ & $\mathrm{SMA}$ & SD & - \\
3 & $\mathrm{Ys}$ & $\mathrm{Rn}$ & - & SD & $\begin{array}{l}\text { Sekolah hanya sampai } \\
\text { kelas 2 SD }\end{array}$ \\
& & & & & - \\
\hline
\end{tabular}

Sumber: hasil wawancara di Desa Tanjung Sari

Faktor kesamaan sosial dan ekonomi tidak menjadi ukuran dalam hubungan perkawinan campuran antar etnis Dayak dengan etnis Jawa, meskipun latar belakang pendidikan yang rendah tidak menjadi hambatan Al menikah dengan Jm. Hasil penelitian tersebut bertolak belakang dengan pendapat Lewis (1997:68). Menurut Lewis yang menyebabkan terjadinya perkawinan campuran salah satunya kesamaan sosial dan ekonomi, orang itu hanya akan menikah dengan seseorang yang latar belakang status ekonominya sudah mapan. Bukan hanya yang bersangkutan yang bersifat demikian, akan tetapi pihak orang tua dan kerabat lainnya.

Kenyataan yang di alami oleh pasangan kawin campur antar etnis Dayak dengan etnis Jawa di Desa Tanjung Sari faktor kesamaan sosial dan ekonomi tidak menjadi hambatan untuk melakukan perkawinan campuran antar etnis, banyak pasangan yang menikah dengan latar belakang status sosial ekonominya rendah, setara dan menengah. Ini ditunjukkan dengan hubungan perkawinan pasangan yang masih tetap terbina secara rukun dan harmonis. 


\section{Perbaikan Keturunan}

Wawasan dan pandangan seseorang yang berasal dari keturunan dua kebudayaan berbeda, pria bersuku Jawa yang menikah dengan wanita Dayak menganggap pernikahannya sebagai suatu hal yang menguntungkan. Secara politis keturunan Jawa dapat berlindung di balik orang Dayak, karena mempunyai keunggulan sebagai masyarakat lokal .

Pasangan suami istri kawin campur yang ada di Desa Tanjung Sari merasa bangga menikah dengan etnis Dayak yaitu sebagai orang pribumi, karena bagi pasangan suami istri kawin campur etnis Dayak memiliki keunggulan yang dapat melindungi, memberikan rasa aman bagi keluarganya dan dapat memberikan keturunan.

Keluarga merupakan suatu hal yang sangat penting bagi perkembangan emosi para anggotanya. Pasangan kawin campur antar etnis Dayak dengan etnis Jawa yang memiliki keturunan akan menjalankan fungsi keluarga dan tujuan dari perkawinan. Horton dan Hunt (1992) melihat keluarga sebagai unit terkecil dari masyarakat yang memiliki beberapa fungsi berikut:

1. Fungsi afeksi, yaitu pemenuhan kebutuhan individu akan cinta dan keamanan emosional.

2. Fungsi sosialisasi, yaitu sebagai tempat penanaman nilai dan peran sosial di masyarakat, dan keluarga memenuhi kebutuhan untuk bersosialisasi dengan anak.

3. Fungsi reproduksi, pemenuhan kebutuhan untuk menghasilkan generasi baru.

4. Fungsi proteksi, kebutuhan untuk melindungi kaum muda dan orang cacat yang dilayani oleh keluarga.

5. Fungsi ekonomi, yaitu sebagai tempat untuk memenuhi kebutuhan kehidupan ekonomi.

6. Fungsi edukasi, yaitu memberikan pengetahuan dan keterampilan pada semua anggota keluarga.

7. Fungsi pengawasan sosial, yaitu sebagai tempat untuk melakukan pengawasan terhadap perilaku moral dan sosial dari anggota keluarga. 
Kebahagian keluarga dapat di peroleh apabila memerankan fungsinya secara baik. Fungsi dasar keluarga dapat memberikan rasa meimiliki, rasa aman, kasih sayang dan mengembangkan hubungan yang baik diantaranya anggota keluarga. Hubungan cinta kasih dalam keluarga tidak sebatas perasaan, akan tetapi juga menyangkut pemeliharaan, rasa tanggung jawab, perhatian, pemahaman, respek dan keinginan untuk menumbuhkembangkan anak yang dicintainya.

\section{Inklusifitas (Keterbukaan, fleksibilitas, toleransi, dan kepekaan terhadap pasangan)}

Hidup dalam satu keluarga perkawinan campuran dengan segala perbedaan yang ada memungkinkan terjadinya berbagai permasalahan yang muncul dalam membangun suatu keluarga, baik bagi pasangan itu sendiri, maupun anak yang dilahirkan. Keterbukaan dalam setiap pasangan, saling memahami, mempelajari perbedaan budaya, menghargai dan peka terhadap pasangan sehingga terciptanya keluarga yang rukun dan harmonis sangat dibutuhkan dalam suatu keluarga.

Masalah yang terjadi pada umumnya yang dialami oleh pasangan kawin campur yang saling mencintai tetapi tidak direstui oleh orang tua, adanya paksaan dan tekanan untuk menerima budaya pasangannya, keluarga yang terlalu sering ikut campur dan belum lagi perbedaan bahasa cenderung muncul kesalahpahaman karena dua bahasa yang di gunakan dalam kehidupan sehari-hari sehingga menimbulkan konflik.

Kondisi permaslahan tersebut di atas sesuai dengan pendapat Dodd (1998: 70-71) menggolongkannya ke dalam delapan kategori yang dapat mempengaruhi perkawinan campuran sebagai berikut:

1. efek Romeo dan Juliet: Konsep ini merujuk pada pasangan kawin campur yang saling tertarik, meskipun keluarga masing-masing tidak memberikan restu. Sayangnya, seiring waktu, pasangan akan menemui beragam persoalan, seperti tidak diterima oleh komunitas, munculnya kritik dari orang-orang terdekat, orangtua melakukan intervensi. Hal ini akan menurunkan kepercayaan individu terhadap pasangannya, 
2. Peran yang diharapkan: Beberapa studi memperlihatkan, bahwa para isteri merasa dipaksa untuk menerima budaya suaminya. Para isteri yang seringkali mengalami tekanan untuk melakukan penyesuaian diri terhadap budaya para suami. Hal ini mengakibatkan turunnya kepuasan dalam berkomunikasi,

3. Gangguan dari keluarga besar: Bagi keluarga kawin campur, persoalan seputar ikut campurnya atau evaluasi oleh keluarga besar lebih sering dijumpai dibandingkan dengan keluarga yang menikah dalam satu budaya,

4. Budaya kolektif-individualistik: beberapa budaya menganut pendekatan saling berbagi sesuai dengan komitmen dan tanggung jawab dalam kelompok (keluarga besar). Tetapi terdapat pula budaya yang lebih memperhatikan kebutuhan keluarganya sendiri dan lebih individualistik,

5. Bahasa dan kesalahpahaman: ketika dua bahasa yang berbeda dipakai dalam kehidupan sehari-hari keluarga kawin campur, seringkali menghasilkan konflik, paling tidak persoalan kesalahpahaman terhadap kata-kata, bahasa yang dipilih untuk dipakai sehari-hari, atau kekuasaan psikologis yang akan mengontrol rumah tangga. Sebagai catatan, jika seorang anak dipaksa untuk memilih identitas kulturalnya, cenderung akan memilih budaya ibunya,

6. Model konflik: Perbedaan dalam cara memecahkan konflik juga merupakan poin penting kehidupan pasangan kawin campur. Directnessindirectness, budaya konteks tinggi konteks rendah, dan jarak kekuasaan merupakan faktor-faktor yang berhubungan dengan konflik dalam keluarga kawin campur,

7. Cara membesarkan anak: perilaku terhadap anak dan cara mendidik anak merepresentasikan perbedaan budaya yang lain dalam keluarga kawin campur. Beberapa budaya menganut pemberlakuan aturan yang ketat dibandingkan budaya lain, yang akan menghasilkan nilai budaya yang berbeda, sekaligus perbedaan cara nilai-nilai tersebut dikomunikasikan dan diberlakukan kepada anak-anak, 
8. Pandangan negatif dari komunitas: Dodd (1998:71) mengajukan pertanyaan kepada 549 orang tentang perkawinan orang Yahudi; Yahudi Barat dengan Yahudi Barat, Yahudi Timur dengan Yahudi Timur dan Yahudi Barat dengan Yahudi Timur. Hasilnya, 25 persen beranggapan, bahwa perkawinan antara orang Yahudi Barat dengan Yahudi Timur tidak akan berhasil dalam perkawinannya.

Pasangan kawin campur antar etnis Dayak dengan etnis Jawa di Desa Tanjung Sari dapat memahami dan mengerti apa yang diinginkan dari pasangannya yaitu suami maupun istri, sehingga adanya sikap saling menyesuaikan, sikap toleransi, saling memahami, mengalah, menghargai, dan percaya, sehingga terwujudnya keluarga yang rukun dan harmonis itu di karenakan beberapa faktor, seperti yang di ungkapakan oleh Fuad (2006:9-11) yang telah di ungkapkan sebelumnya di atas, yaitu:

\section{Toleransi}

Toleransi adalah suatu sikap saling menghormati perbedaan yang ada pada berbagai aspek budaya dan keyakinan, seperti menghormati perbedaan adat istiadat, sistem norma dan nilai serta kebiasaan dalam suatu kebudayaan atau keyakinan serta membiarkan (tenggang rasa) pada pihak lain untuk melaksanakan adat istiadat, sistem norma dan nilai, kebiasaan serta keyakinan yang dianutnya.

\section{Kerjasama}

Kerjasama adalah suatu keadaan di mana para individu atau kelompok masyarakat melakukan hubungan timbal balik dengan pembagian tugas dan atas dasar saling membutuhkan dan saling ketergantungan satu sama lain untuk mencapai tujuan yang telah ditetapkan bersama.

\section{Menghargai Simbol Kebudayaan}

Simbol kebudayaan adalah berbagai tanda baik berupa benda-benda fisik maupun nonfisik yang melambangkan nilai-nilai dan sistem yang ada 
pada kebudayaan tersebut. Manusia telah menciptakan berbagai simbol untuk mengingatkan dengan cepat mengenai suatu lembaga, misalnya simbol kebudayaan dalam keluarga dilambangkan dengan cincin kawin.

\section{Perilaku Dalam Keluarga}

Perilaku dalam keluarga adalah seperangkat tatanan tingkah laku yang dilaksanakan oleh anggota-anggota keluarga berdasarkan peranannya masingmasing dalam keluarga tersebut. Orang yang terlibat dalam suatu lembaga keluarga dipersiapkan untuk melaksanakan peranannya secara tepat. Peran itu seringkali diungkapkan dalam kode (norma) yang resmi, seperti janji pernikahan dan sumpah setia terhadap Tuhan.

Temuan hasil penelitian bahwa pasangan yang melakukan perkawinan campuran antar etnis Dayak dengan etnis Jawa dilatar belakangi oleh faktor ketertarikan fisik dan inklusifitas (keterbukaan, fleksibilitas, toleransi dan kepekaan terhadap pasangan). Berikut ini adalah hasil temuan faktor-faktor yang melatar belakangi terjadinya perkawinan campuran antar etnis Dayak dengan etnis Jawa di Desa Tanjung Sari.

Tabel 4. Faktor yang mempengaruhi terjadinya perkawinan campuran antar etnis Dayak dengan etnis Jawa di Desa Tanjung Sari

\begin{tabular}{|c|c|c|}
\hline No & Faktor & Bentuk \\
\hline 1 & Ketertarikan Fisk & $\begin{array}{l}\text { Wanita yang beretnis Dayak memiliki } \\
\text { paras cantik, berkulit putih dan } \\
\text { pekerja keras. }\end{array}$ \\
\hline 2 & $\begin{array}{l}\text { Inklusifitas } \\
\text { (keterbukaan, } \\
\text { fleksibilitas, } \\
\text { mebghargai } \\
\text { kepekaan } \\
\text { pasangan) }\end{array}$ & $\begin{array}{l}\text { Menerima kekurangan pasangannya, } \\
\text { menghargai perbedaan, saling } \\
\text { pengertian, membantu, saling } \\
\text { percaya, mengimbangi, adanya } \\
\text { kesepakatan dan jujur. }\end{array}$ \\
\hline
\end{tabular}

Hasil temuan penelitian, yaitu pertama faktor ketertarikan fisik dan inklusifitas (keterbukaan, fleksibel, toleransi, menghargai, dan peka terhadapa pasangan). Kedua factor tersebut merupakan faktor yang mempengaruhi 
terjadinya perkawinan campuran antar etnis Dayak dengan etnis Jawa di Desa Tanjung Sari Kecamatan Nanga Pinoh Kalimantan Barat.

Latar belakang fisik merupakan faktor utama seseorang dalam memilih pasangan dan sebagai penentu terjadinya pernikahan, sedang faktor lainnya kesamaan sosial dan ekonomi serta perbaikan keturunan bagi pasangan perkawinan campuran antar etnis Dayak dengan etnis Jawa di Desa Tanjung Sari tidak menjadi ukuran dalam memilih pasangan hidup.

Inklusifitas merupakan factor terpenting dalam suatu hubungan dengan latar belakang yang berbeda antar etnis Dayak dengan etnis Jawa. Inklusifitas yaitu adanya sikap keterbukaan setiap pasangan menerima kekurangan dan kelebihan, fleksibilitas, memiliki sikap toleransi pada pasangan yang memiliki perbedaan latar belakang agama dan budaya dengan menghargai segala bentuk usaha yang dilakukan pasangan, saling percaya, memahami dan kepekaan terhadap pasangan, sehingga terwujudnya keluarga yang rukun dan harmonis.

\section{SIMPULAN}

Dari analisis di atas, ada dua hal kecenderungan dari perkawinan campuran etnis Dayak dan etnis Jawa:

1. Fisik yang berkaitan dengan lahiriah, sebagai sebagai tolak ukur perkawinan yaitu yang bermakna pada cinta sejati-batiniah, yang ditopang oleh Keterfleksian (keterbukaan, fleksibel, toleransi,kepekaan) sehingga mampu membangun kebersamaan, kerukunan dalam rumah tangga. Kondisi seperti ini, segala perbedaan yang ada, akhirnya dapat di atasi secara bersama tanpa menimbulkan konflik.

2. Cinta sejati yang berkaitan dengan batiniah, sebagai tolak ukur perkawinan yang mampu mereduksi perbedaan-perbedaan dari kedua belah pihak, ditopang oleh Keterfleksian (keterbukaan, fleksibel, toleransi, kepekaan) sehingga mampu membangun kebersamaan, kerukunan dalam rumah tangga.

Dengan demikian dalam perkawinan campuran antara etnis Dayak dengan etnis Jawa di Desa Tanjung Sari, Kecamatan Nanga Pinoh, Kabupaten Melawi yang menjadi daya pengikat utama yaitu fisik dan cinta sejati yang ditopang oleh 
keterfeksian (keterbukaan, fleksibel, toleransi, kepekaan) sehingga terjadinya perkawinan campuran antar etnis Dayak dengan etnsi Jawa yang dapat mewujudkan kebersamaan, kerukunan dan terhindar dari konflik. Segala bentuk ancaman, tantangan, hambatan dan gangguan dari perbedaan ras, budaya, dan agama tidak berpengaruh terhadap kerukunan dan kesatuan bangsa. Tindakan yang dilakukan oleh masyarakat Desa Tanjung Sari tanpa di sadari telah mempraktekkan multikultur dan sebagain pendukung multikultur, karena mau menerima keragaman sosial-budaya sebagai suatu kenyataan, memiliki sikap toleransi, berbaik sangka dan keterbukaan antar kelompok masyarakat.

\section{UCAPAN TERIMAKASIH}

1. Masyarakat tetap menghargai, menjunjung, dan melestarikan kebudayaan yang dimiliki setiap pasangan, walaupun melakukan perkawinan campuran, perlu adanya sosialisasi tentang perkawinan campuran untuk pasangan yang akan melakukan perkawinan campuran antar etnis oleh pihak terkait agar pasangan yang melakukan perkawinan campur memahami undang-undang perkawinan campuran dan perlu dicontoh oleh etnis lainnya selain etnis Dayak dan Jawa dalam melakukan perkawinan campuran. di Desa yang ada di Kecamatan Nanga Pinoh.

2. Bagi pemerintah dan pengambil kebijakan perlunya pendataan bagi pasangan yang melakukan perkawinan campuran antar etnis oleh pihak Kecamatan ke Desa - Desa di Kecamatan Nanga Pinoh.

3. Bagi penelitian lainnya keterbatasan hasil penelitian tentang faktor yang mempengfaruhi perkawinan campuran antar etnis Dayak dengan Jawa di Desa Tanjung Sari dapat menjadi bahan kajian penelitian lainnya.

\section{DAFTAR PUSTAKA}

Arif, M. J. Akien. 1993. Kehidupan Sosial Ekonomi Orang Dayak, Dalam: Kalimantan Review, Nomor 03 Tahun II, Januari-April. Pontianak: LP3ESInstitut of Dayakology Research and Development. 
MASA: Journal of History, Vol. 1, No. 2, Desember 2019

Creswell, J.W. 2014. Research Design: Pendidikan Kualitatif, Kuantitatif, dan Mixed. Yogyakarta: Pustaka Belajar.

Dodd, Carley H. 1998. Dynamic of Intercultural Communication (Fifth Edition). USA: The McGraw-Hill Companies. Inc.

Endraswara, S. 2015. Etnologi Jawa. Peneitian, Perbandingan, Dan Pemaknaan Buday. CAPS. Yogyakarta.

Fuad Shalih, Syaikh. 2006. Menjadi Pengantin Sepanjang Masa. Solo: Aqwam Media Profetika.

http://repo.unand.ac.id/2798/1/1974_UU-1-TAHUN-1974_PERKAWINAN.pdf

Horton, Paul B dan Hunt, Chester L. 1999. Sosiologi Jilid 2. Di Indonesiakan oleh Aminuddin Ram dan Tita Sobari. Jakarta: Penerbit Erlangga.

Thamrin, Khazin, Mohd. 1988. Orang Jawa di Borneo Utara: Satu Nota Awal. Jurnal Jebat, volume 16, halaman123-136.

Lewis, R., Yancey, G., \& Bletzer, S.S. (1997). Racial and nonracial factors that influence spouse choice in black/white marriages. Journal of Black Studies, volume 28, Nomor 1, halaman 60-78.

Miles and Huberman. 1992. Qualitative data Analisis. London: Sage Publication.

Peterianus, S. 2014. Orientalisme Timur Atas Timur Orientalisme dan Kolonialisme pada Program Transmigrasi di Kalimantan Barat. Yogyakarta: Jogja Bangkit Publisher.

Sugiyono. 2014. Memahami Penelitian Kualitatif. Bandung: Alfabeta. 